\title{
PHYSICAL OCEANOGRAPHY IN ATLANTIC CANADA
}

\author{
R. ALLYN CLARKE \\ Ocean Sciences Division, Science Branch \\ Department of Fisheries and Oceans, Maritimes Region \\ Bedford Institute of Oceanography \\ PO Box 1006 \\ Dartmouth, Nova Scotia B2Y $4 A 2$
}

\begin{abstract}
Physical oceanography has been practiced in Atlantic Canada since the beginnings of the science in the second half of the $19^{\text {th }}$ century. Pursued largely as an applied science, its efforts have been directed toward providing information to mariners and other marine users. Early efforts focused on tidal observations to promote safe navigation. This was expanded in the early $20^{\text {th }}$ century to regional studies in support of fisheries. In the second half of the $20^{\text {th }}$ century, physical oceanography in Atlantic Canada grew to support the offshore development of oil and gas, provide more comprehensive environmental assessments of marine projects and processes, improve Search and Rescue responses and to better understand and predict climate change and variability. Oceanographers now have the capabilities to observe the ocean in near real-time using satellites as well as autonomous in situ instruments. The continued growth in computer power and other information technologies has permitted the development of operational ocean models that can provide real-time information and projections on oceanic conditions to a broad section of the marine community.
\end{abstract}

L'océanographie physique est pratiquée au Canada atlantique depuis les débuts de cette science au cours de la deuxième moitié du XIX siècle. Les travaux dans ce domaine, menés dans une grande mesure sous forme appliquée, sont axés principalement sur la fourniture de renseignements aux gens de mer et aux autres utilisateurs du milieu marin. Les premiers travaux ont porté sur les observations des marées afin d'assurer la sécurité en mer. Au début du XX $X^{e}$ siècle, des études régionales ont été lancées pour appuyer les activités de pêche. Au cours de la deuxième moitié du XXe siècle, l'océanographie physique au Canada atlantique a continué de croître pour maintenant appuyer les projets de mise en valeur du pétrole et du gaz en milieu extracôtier, fournir des évaluations environnementales plus détaillées des projets en milieu marin et des processus liés à ce milieu, améliorer l'intervention dans le cadre d'opérations de recherche et de sauvetage, approfondir les connaissances sur le changement climatique et la variabilité et améliorer les prévisions relatives à ceux-ci. Les océanographes ont maintenant la capacité d'observer l'océan presque en temps réel grâce à des satellites et à des instruments autonomes in situ. L'amélioration continue de la puissance des ordinateurs et d'autres technologies de l'information a rendu possible l'élaboration de modèles océaniques opérationnels qui peuvent fournir des données et prévisions en temps réel sur les conditions océaniques à une part importante de la communauté maritime.

\section{INTRODUCTION}

Physical oceanography describes, analyzes, models and predicts the physical marine environment and is focused primarily on ocean waves, tides, currents as well as ocean temperatures and salinities. Early oceanography 
was concerned principally with observation and description, but with the advance of scientific understanding and computing capacity, modeling and prediction has become a significant activity. It is a young science that arose in the nineteenth century, its development driven both by intellectual curiosity and by the needs of commerce and the military for better information on ocean winds, currents and tides.

Mariners have always observed the ocean and obtained a great deal of practical local information on ocean currents and tides as well as the location and behaviour of its living resources. From ancient times, this knowledge was preserved in stories, songs and poems, e.g. the Norse sagas. Systematic ocean observations began with Prince Henry the Navigator of Portugal, who directed the collection and codification of ocean observations, creating knowledge that supported the expansion of the Portuguese empire to Africa, Brazil and into the Indian Ocean. During the nineteenth century, both the US and British navies began the systematic collection of wind, current, pressure and temperature observations from the logs of commercial and naval vessels throughout the world. The international collection and exchange of these data were arranged at international conferences in 1853 and 1873. These data were synthesized into monthly pilot charts that allowed navigators to plan voyages on the basis of expected wind and surface current patterns. As these charts revealed the patterns of winds and currents, they became the basis of theories of global atmospheric and oceanic circulation.

The HMS Challenger expedition, 1872-1876, is usually considered to mark the birth of oceanography as a science. Halifax was this vessel's first port of call after it had occupied a series of oceanographic stations across the North Atlantic from England. The Challenger, on its departure from Halifax, occupied 8 oceanographic stations from the outer edge of the Scotian Shelf to Bermuda in May 1873 (Fig 1), perhaps the first oceanographic section across the Gulf Stream south of Nova Scotia. Much of the organization of the Challenger expedition was carried on by Sir John Murray, a Scottishtrained naturalist born in 1841 in Coburg, Ontario, for whom one of the buildings at the Bedford Institute of Oceanography is named.

Oceanography in Atlantic Canada began with the establishment of a tide gauge network in 1893-1895. In addition, W.B. Dawson carried out a series of tide and current surveys in 1894, 1895 and 1896 using the lighthouse supply steamer, Landsdowne and in 1903 the steamer, Gulnare. These surveys provided the observational basis for the prediction of the timing and strength of tidal currents in many of the key straits and passages of Atlantic Canada and established a better information base for marine transportation in the area.

Early global expeditions such as the Challenger expedition yielded a broad description of the physical, chemical and biological distributions in the oceans, but were not able to delineate the physical processes that governed those distributions. At the beginning of the 20th century, Nordic oceanographers and meteorologists were developing the theoretical basis 

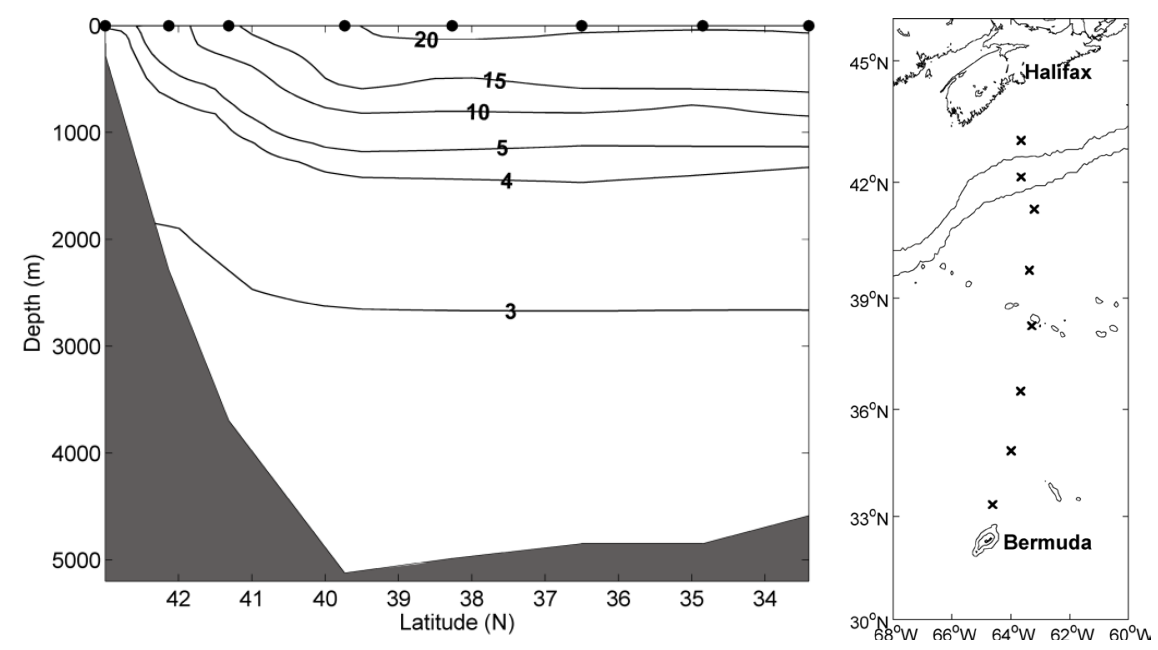

Fig 1 HMS Challenger temperature sections from the outer Scotian Shelf to Bermuda, May 1873. Sampling positions are indicated by a dot at $0 \mathrm{~m}$ in the section and as an $\mathrm{x}$ on the map. The average station spacing of $\sim 160 \mathrm{~km}$ is too coarse to resolve the Gulf Stream well, but the upward tilting temperature contours place the Stream near the base of the continental slope.

of the dynamics of the oceans and atmosphere and thereby pioneered the design of well-planned, systematic surveys of regional oceanographic features and processes.

The first systematic survey of the physical oceanography of Atlantic Canada undertaken by Canada was the 1914 -1915 Canadian Fisheries Expedition (Bjerkan 1919, Sandstrom 1919) led by Dr. J. Hjort, Director of Fisheries for Norway. This was the beginning of efforts to relate fisheries variations to changes in oceanographic conditions. Throughout the 1920s and 30 s, physical oceanography was an integral part of the fisheries related research programs carried out by federal fisheries laboratories in Atlantic Canada, especially at the St Andrews Biological Station.

The St Andrews Biological Station began as a small floating laboratory in the summers of 1899 and 1900 . The laboratory was operated in subsequent summers in various locations in both the Maritimes and Quebec before a permanent laboratory was established at the present site in St Andrews, NB in the summer of 1908. During its early years, much of the science was conducted only during the summers by researchers from Canadian universities. The work of the station included physical oceanography from at least as early as 1914 when a hydrographic section was occupied in the Bay of Fundy (Craigie 1916). In 1921, the station began making daily sea surface measurements, a practice that has continued to this day with notable gaps in 1985/86 and 2001/02. This is Canada's longest record of coastal ocean temperature (Fig 2), exceeded only by the record from Booth Bay Harbor, Maine which began in 1906. 




Fig 2 Sea surface temperature at St Andrews, New Brunswick. The annual average temperatures (grey dots, line) and the 5 year averages (heavy black line) are shown.

A Canadian pioneer in the physics of the oceans, Dr Howard Turner Barnes of McGill University, published, from 1906 through to 1929, a number of studies on the impact of icebergs on sea and air temperatures and on marine organisms as well as exploring ways to detect and destroy icebergs at sea. During the First World War, he also provided advice on the detection of submarines.

Physical oceanography in Atlantic Canada was strengthened when HB Hachey, then a member of the Department of Physics at the University of New Brunswick in Fredericton began in the late 1920s to spend his summers working at St Andrews (Campbell 1985). In 1930, he led the first research cruise into Hudson Bay, observing the water masses, currents, circulation, plankton and fish for the primary purpose of assessing its fisheries potential. Over the next three decades, Hachey wrote papers describing the regional oceanography of Atlantic Canada; the ideas developed in these papers still form the basis of our understanding of the ocean currents and circulation of Atlantic Canada (Hachey 1961).

The post World War II period saw a worldwide expansion of oceanography and Canada was no exception. The Canadian Committee on Oceanography, a body of senior managers of federal government and university departments with oceanographic capacity, planned and coordinated the remarkable growth of the Canadian Marine Sciences community. Institutes of Oceanography were established as graduate research organizations at the University of British Columbia and Dalhousie University to train Canadian oceanographers needed to support the creation of the new government laboratories and institutes.

Federal government physical, chemical and biological oceanographic and marine geophysical capacities in Atlantic Canada were significantly increased with the establishment of the Bedford Institute of Oceanography 
(BIO) in 1962. At the time of its opening, BIO was occupied by scientists and hydrographers from both the Department of Mines and Technical Surveys and the Fisheries Research Board of Canada. It also supplied oceanographers to the Meteorological and Oceanographic Centre of the Canadian Navy and its programs often involved faculty and students from Dalhousie and other Canadian universities. This tradition of co-operation and collaboration across departmental boundaries functioned well, but was severely stressed by financial and organizational changes imposed during the program reviews of the 1990s. Fortunately, it still remains an important part of the way that oceanography is pursued in Atlantic Canada.

With the new BIO also came a fleet of one older and two new oceanographic / hydrographic vessels designed to work year round in the coastal and offshore waters of Atlantic Canada and the Arctic Archipelago. These included Baffin (in service from 1956), Hudson (1962) and Dawson (1970). Engineers, working with the physical oceanographers, developed deep sea and shelf mooring techniques that allowed self-recording current meters and thermosalinographs to be deployed for months to years at selected sites around the region. Over its first 25 years, $\mathrm{BIO}$ oceanographers mapped the water masses, currents and circulation of the North Atlantic from Bermuda and the Canaries to Svalbard, Ellesmere Island and the Arctic Archipelago. Canadian oceanographers and hydrographers carried out programs in the Caribbean, the tropical Pacific and Atlantic and even the Southern Ocean during the Hudson '70 circumnavigation of the Americas.

Halifax-Dartmouth is not the only centre of oceanographic expertise in Atlantic Canada. Oceanography has remained a part of the St Andrew's Biological Station program for more than a century. The Fisheries Station in St John's Newfoundland has also had a long history of observing and analyzing the variability of the physical environment of the Newfoundland and Labrador shelves; these activities are now part of the Northwest Atlantic Fisheries Centre programs. The government of Newfoundland has also made the study of the cold ocean a strategic priority with the result that Memorial University has built significant capacity in physical oceanography and ocean engineering over the past two to three decades.

The Gulf of St Lawrence is an important Atlantic Canadian marginal sea displaying many of the physical processes found in high latitude oceans. It has been an area of physical oceanographic studies since the tidal current surveys of Dawson at the end of the nineteenth century. Oceanographers at StAndrews and at the Bedford Institute of Oceanography continued to study the Gulf through to the 1980s. With the development of oceanography at the University of Québec at Rimouski and the establishment of the Maurice Lamontange Institute at Mount Joli, the responsibility for Gulf of St Lawrence studies was transferred to these Québec oceanographic groups.

Over the past one hundred and thirty years, oceanography globally and within Canada evolved through several different stages. In the early years, oceanography was exploratory consisting mainly of scientists taking a few widely scattered observations simply to observe some part of a largely 
unknown ocean environment. This was followed by a systematic mapping phase. The third stage focused on observational, theoretical and modeling studies of particular oceanic processes. In my view, oceanography is just entering the fourth stage which consists of the routine operational production and delivery of ocean analysis and predictions to the marine and climate communities.

At the beginning of the twenty-first century, oceanography still pursues activities within all four stages, but new instruments and techniques open new areas and aspects of the ocean to our view. These are first explored extensively before being subjected to more complete observation and analysis. As the oceans are always changing, there must be systematic, ongoing mapping. These sustained observations are designed as part of ocean information systems in which observations feed ocean models which then produce analyses and maps directed to different marine users. As our understanding of ocean processes will always be incomplete, oceanographic research must continue. Increasingly, oceanographic research is directed towards interactions between the physical, biological and geochemical environment.

\section{THE OCEAN'S ROLE IN CLIMATE AND WEATHER}

The oceans cover $70 \%$ of the surface of the earth and consequently play an important role in the climate system (Fig 3 ) by storing and transporting

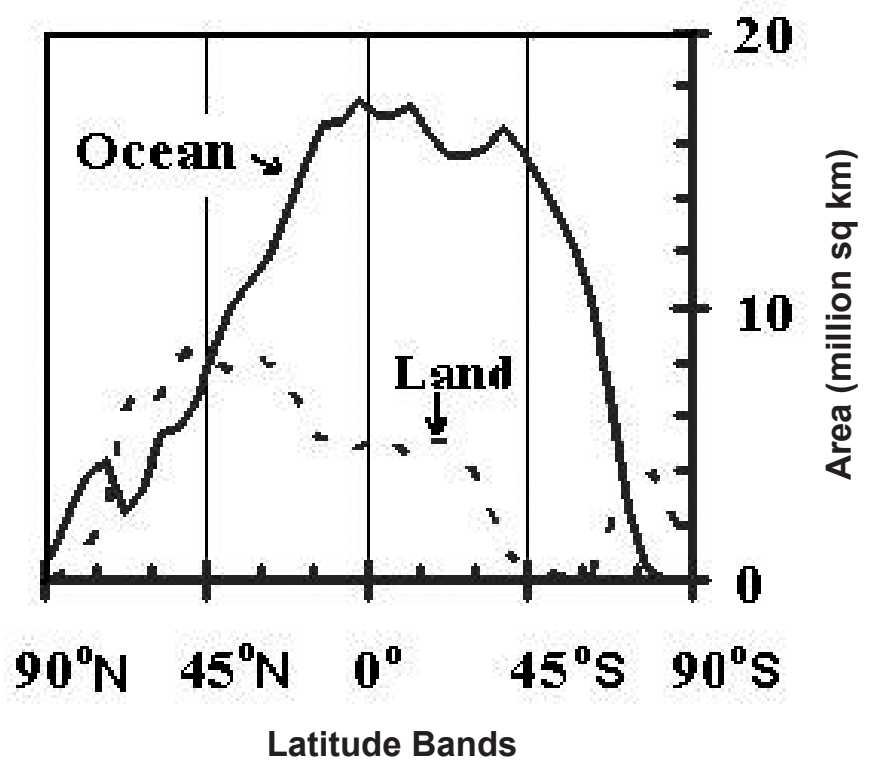

Fig 3 Zonal distribution of land and ocean. 
large amounts of heat, water and radiatively active gases. These processes generally act to moderate changes in weather and climate. Temperatures over the oceans fluctuate less from day to night and from summer to winter than those found over the land; as one result spring warming is delayed, and so is fall cooling. Ocean processes cool the tropics and warm the higher latitudes making more of the globe favourable to life.

Ocean processes also support weather and climate variability and change. The warm waters of the tropical oceans generate tropical storms during summer and fall; warm ocean waters cause mid-latitude winter storms to strengthen explosively when the winds move from over land to over the ocean. Temperature anomalies in ocean surface waters are associated with large-scale climatic variability such as the EI Niño Southern Oscillation (ENSO) phenomenon. Ocean processes are also believed to play key roles in the rapid changes of our climate system between glacial and interglacial states. Because of these important roles, Canada began in the 1990s to participate in the design and the implementation of a global ocean observing system for climate.

The climate system is driven by solar energy. When the climate is in a steady state, the earth radiates back to space all the energy that it receives. Almost one third of the incoming solar radiation is reflected back to space by clouds, aerosols, the atmosphere and the earth's surface; nearly half is absorbed at the earth's surface leaving less than $20 \%$ directly absorbed by the atmosphere. The earth's surface, including the ocean, plays a dominant role in providing the energy that drives atmospheric dynamics, creating weather and atmospheric climate. Energy is transferred from the surface into the atmosphere through radiation, evaporation, transpiration and thermal conduction.

Much of the extreme weather in Atlantic Canada has an oceanic origin. In the late summer and fall, the region experiences tropical storms. These small but intense systems are born through convection over the warm (> $28^{\circ} \mathrm{C}$ ) surface waters of the tropical North Atlantic and are carried westward toward the Caribbean and Gulf of Mexico by the trade winds. Some of these storms turn northward traversing the warm surface waters of the Sargasso Sea which, especially at the end of the summer, allow them to move northward for several days while retaining much of their energy. Most remain offshore where their strong winds and confused seas are a hazard to shipping and other marine activities. Other tropical storms come ashore in Atlantic Canada wreaking havoc with their high winds, elevated sea levels, large waves and heavy rainfall.

During the winter months, Atlantic Canada is subjected to large and intense storms that move eastward across North America south of the Great Lakes before moving out over the ocean between Washington and New York cities. When they move from the land to the much warmer ocean, these storms intensify quickly and move northeasterly toward and through Atlantic Canada and its offshore waters. The prediction of the magnitude of the intensification and their subsequent trajectory and development is a 
challenge to the current weather models. Continued research on air-sea exchanges of momentum, heat and water vapour as well as improvements in the parameterizations of these processes in the weather forecast models continue to be pursued in Canada and elsewhere.

The forecasting of tropical and marine storms requires knowledge of the observed sea surface temperatures (SST), as these control the ocean / atmosphere exchange of heat and water vapour that will govern the development of the storm. For example, Hurricane Juan, in 2003, was able to sustain itself as a Category Two hurricane as it came ashore at Halifax because of the anomalously warm surface and upper ocean temperatures between the Gulf Stream and the coast of Nova Scotia. Currently, the SST field from satellite observations is included in weather forecast models. However, the storms extract large amounts of heat from the ocean to the atmosphere thereby cooling the ocean surface. The next generation of models will include information about the upper ocean so that the model can forecast the changing SST field and through this better predict the overall development of the storm. Since 2000, BIO oceanographers have maintained an array of autonomous instruments that provide the necessary real-time observations of the sub-surface temperature and salinity profiles from the Northwest North Atlantic as a Canadian contribution to a global array.

Over most of the world's oceans, only the uppermost 50 to 400 metres participate directly in the seasonal cycle of heat accumulation and release. Only in a few restricted regions of the North Atlantic and the Southern Ocean do the dense waters that fill the ocean depths come in contact with the atmosphere. One of these regions is in the Labrador Sea just outside Canadian waters. Because Canada's oceanographic vessels were capable of working in ice and winter conditions, it was not surprising that the study of the transformations of these deep waters has become an area of special Canadian interest and expertise. The winter survey of the entire sub-polar gyre of the North Atlantic in 1965 - 1967 (Fig 4) has remained the definitive description of this regime for fully 3 decades (Grant 1968). Understanding these processes is an important part of understanding the oceans' role in the climate system.

The oceans are also important reservoirs of all the significant greenhouse gases produced and found in the lower atmosphere. For example, the oceans contain 1000 times more carbon dioxide than does the atmosphere. The upper ocean exchanges about 100 gigatonnes of carbon in the form of carbon dioxide with the atmosphere during the seasonal cycle. About 100 gigatonnes flows from the atmosphere to the oceans when the surface ocean is being cooled or where carbon dioxide is being consumed by biological primary productivity while 98 gigatonnes flows back to the atmosphere when the ocean surface warms and biological primary productivity is suppressed. The net annual storage of 2 gigatonnes of carbon represents about a third of the 6 gigatonnes of carbon released by human activities such as burning fossil fuels and carrying out large-scale land use changes. Because the ocean is such a large reservoir of carbon dioxide, 


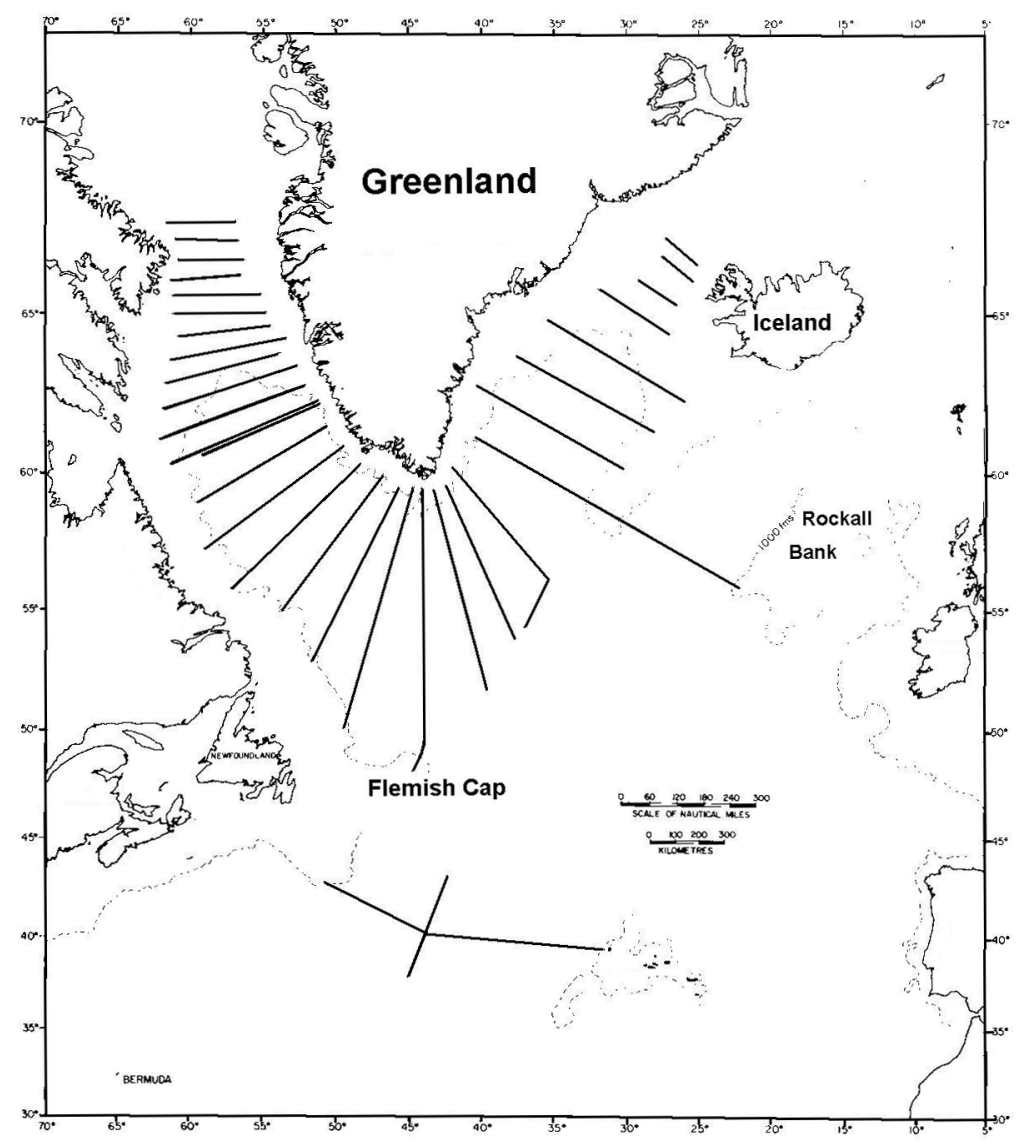

Fig 4 BIO's Sub-polar gyre survey, 1965-1967 (adapted from Grant 1968). Full depth hydrographic stations measuring temperature, salinity and oxygen content were occupied along each of the sections. Silicate and phosphate were measured on many of the stations. Surveys were conducted by CGGS Labrador, CSS Hudson and CSS Baffin.

changes in the oceans' surface temperatures, such as those occurring during EI Niño years, result in variable uptake of $\mathrm{CO}_{2}$ and hence modifying the rate of increase of atmospheric $\mathrm{CO}_{2}$.

During the 1990s, the global oceanographic community carried out the World Ocean Circulation Experiment (WOCE). The goal of this experiment was to develop the global ocean models needed to improve our predictions of climate change as well as to collect the high quality global data set necessary to test those models. Over eight years, oceanographic vessels from all of the major nations of the world spent more than 3000 months at sea occupying a series of north-south and east-west sections across every major ocean basin other than the Arctic Ocean. Measurements of the 
distribution of radioisotopes and modern industrial chemicals along these sections provided new ways to estimate the strength and time scales of the slow, deep, circulations of the ocean.

Atlantic Canadian oceanographers deployed current meter mooring arrays to measure the transport of the North Atlantic Current east of the Grand Banks of Newfoundland and to observe winter convection in the Labrador Sea. Oceanographic sections were occupied across the Labrador Sea and east of Newfoundland. Oceanographers from BIO and Dalhousie University joined American and British scientists in a study on mixing in the ocean thermocline.

Several new technologies were deployed during WOCE. By use of satellite altimeters, a global map of the height of the sea surface was generated every 10 days. This is equivalent to the meteorologist's map of surface air pressure and allows the oceanographer to estimate the strength of the large scale surface currents. Asatellite instrument called a scatterometer was also deployed during WOCE. By measuring the strength of the shortest waves on the sea surface, this instrument estimates the magnitude and direction of the surface wind which primarily drives the ocean surface circulation. For the first time, oceanographers had real-time global observations of both wind forcing and strength of the surface circulation. In addition to these satellite observations, WOCE developed and deployed surface and deep drifters to measure the current field at the sea surface and 1500 metres.

The rapid growth of computer power greatly assisted the development of global ocean circulation models during WOCE. By the 2000s, computers were large and fast enough to support global ocean models that could resolve most of the relevant physical processes, at least at low and middle latitudes. Improved computer technology also allowed scientists to analyze the large oceanographic data sets, collected during WOCE and earlier, and create appropriate fields to initiate, force and verify these models. This development led to the next generation of coupled atmosphere - ocean models that have been used to generate the climate change projections that formed the basis of the 2001 assessment of climate change performed by the Intergovernmental Panel on Climate Change.

\section{THE OCEAN ENVIRONMENT IN MARINE ECOSYSTEMS AND FISHERIES}

With good reason soon after they began to fish, humans became concerned with the rise and fall of their catches. The history of commercial fisheries is full of examples of vigorous fisheries collapsing to near zero over short periods of time. Aggressive over-exploitation of the fisheries is likely to have played a significant role in these collapses, but paleo-climatic studies also have shown similar patterns existing before commercial fisheries arose (Baumgartner et al. 1992, Finney et al. 2000). As mentioned earlier, the initial goal of large-scale systematic physical oceanography in Atlantic 
Canada was to try to understand the role that ocean variability played in the changes in abundance of commercially important species.

Temperature, salinity, nutrients, solar radiation, waves, currents, trace chemicals, bathymetry and bottom characteristics all play important roles in the health of marine ecosystems at different times within their biological cycles. The marine ecosystem begins with the fixing of carbon dioxide through photosynthesis by phytoplankton and other marine plants. This process is affected by temperature and nutrient concentrations as well as light levels, the stability of the water column and its turbulent energy. Under conditions of low stability or strong turbulence, phytoplankton cannot remain at their optimal light levels. On the other hand, if the surface layer is strongly stable, phytoplankton can rapidly deplete the nutrients because vertical processes such as upwelling and mixing that can replenish nutrients are strongly suppressed.

Higher trophic levels respond to the ocean environment in ways that we are just beginning to understand. By comparing the distributions of particular species with changes in ocean temperatures and salinities, fisheries oceanographers have developed some insight into the range of environmental conditions tolerated by those species. These investigations are complicated by the fact that the ocean environment likely affects marine species differently at each stage of their development. As the organism moves from the egg through various larval and immature stages to spawning adult, it will need particular environmental conditions for optimal growth and survival. During the early stages, ocean temperatures are important for growth and development rates while ocean currents are important to move the eggs and larvae from spawning to nursery areas. As the organism grows, ocean temperature still plays a role in its rate of development. Colder temperatures modify production and availability of food, slow the animal's physiology and hence reduce growth. Warmer temperatures can increase the stress on the animal and also increase the impact of disease and parasites. Specific marine organisms have been adapted to develop best at particular ranges of ocean temperatures; beyond certain thresholds both warmer and colder temperatures can decrease growth and survival.

Of course, a species does not live alone in the ocean. Its growth also depends on the availability of food organisms, the abundance of other species that compete for those same prey, and the concentrations of predators. All vary in response to the ocean environment. Because of this complexity, modern fisheries oceanographers are now focusing on entire marine ecosystem dynamics, rather than single species.

\section{OCEANOGRAPHY IN SUPPORT OF MARINE INDUSTRIES AND SAFETY AT SEA}

When the oil and gas industry began exploring in the offshore waters of Atlantic Canada and the Eastern Arctic, their representatives contacted the physical oceanographers for information on the sea-ice, iceberg and 
wave conditions and ocean currents that would be encountered. Offshore structures and operations have to be designed to withstand the strongest waves and currents that are likely to occur in the desired areas. Compilation and analysis of archived data provided the initial basis, but many new observations were collected to provide site-specific data for the design of both the exploration drilling platforms and the later production facilities. Offshore operators need real-time knowledge of the waves and currents in order to safely carry out critical tasks associated with drilling, supply to the platforms and installation of production infrastructure. When accidents occur, with people or oil slicks possibly adrift, data on the ocean currents are needed to predict their movement and to plan their recovery. The initial physical oceanographic support to the oil and gas industry was provided by BIO; however, during the 1970 s the development of a number of private sector oceanographic groups, through collaboration with both government and university scientists, soon provided a full range of observational and modeling services to industry.

Ocean currents are complex and difficult to measure accurately. They arise from the tides, from the local wind, from the large-scale wind and circulation and from various eddies and planetary waves that might be propagating through the area. They also vary with depth and time. Observing ocean currents is an expensive and time-consuming process because they vary over time scales of minutes to years, and thus observations must be collected over several years to begin to define even the annual cycle. As a result, oceanographers have turned to ocean models to complement their observations.

Ocean modeling is a rapidly developing tool to produce analyses and forecasts based on the data. New research models, however, must be regularly evaluated against the existing operational models under simulated operational conditions at sea. These models, able to simulate the effects of tides, winds, bathymetry and the large-scale ocean circulation for selected regions and to provide real-time estimates and predictions of ocean currents at various depths are used for large engineering projects in the offshore and during marine emergencies. An example was provided by the salvage operations following the crash of Swiss Air flight 111 in September 1998 which were hampered by strong and variable currents over the crash site. $\mathrm{BIO}$ oceanographers quickly created a local ocean model driven by tides and wind forecasts that predicted both surface and subsurface currents throughout the region. These predictions were used successfully to plan each day's operations (Fig 5).

The ocean instrumentation industry of Nova Scotia has developed a number of radio and satellite tracked drifters that simulate the drift of oil slicks or survivors in life jackets, survivor suits or life rafts. These have been used in a series of exercises to test the capabilities of the ocean models in the waters off Nova Scotia. The drifters are deployed by aircraft in Search and Rescue and marine environmental incidents to provide on site observations 

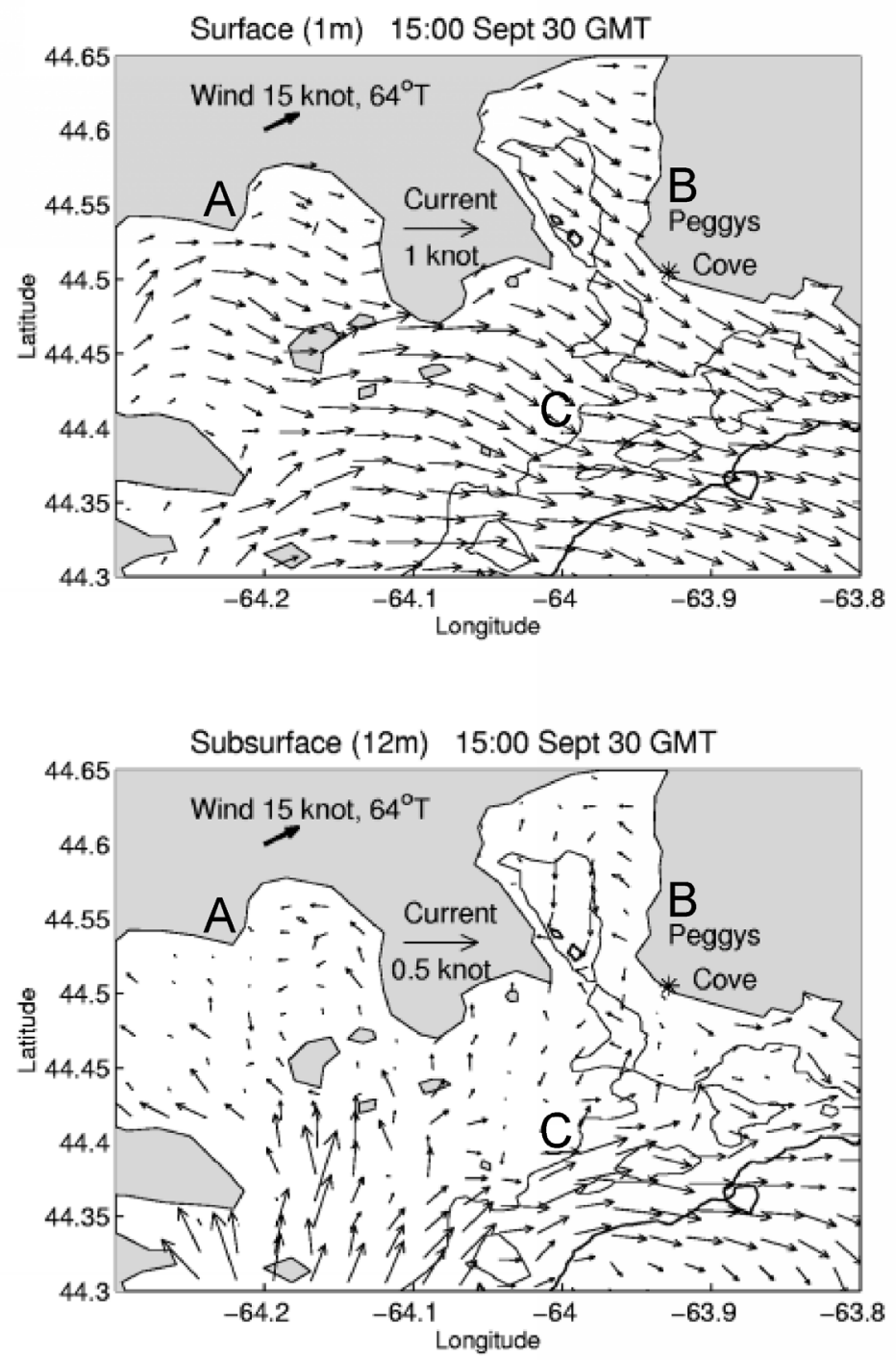

Fig 5 Predicted tidal currents produced for the salvage operations following the crash near Peggy's Cove, Nova Scotia of Swiss Air flight 111, September 2, 1998. The crash site is point ' $C$ '; ' $A$ ' and ' $B$ ' are Mahone and St. Margaret's Bay respectively.

of the ocean currents to directly simulate drifting objects and support the ocean model predictions.

Technology exists that will provide continuous real-time estimates of the surface currents up to 200 kilometres from shore. High frequency systems known as Coastal Ocean Dynamics Application Radar (CODAR) consist of 
small transmitter / receiver stations sited on headlands or offshore islands every 150- $200 \mathrm{~km}$ along a coastline. These systems provide surface current and wave information at $3 \mathrm{~km}$ resolution over the continental shelf. Such a system is being established as part of the Gulf of Maine Ocean Observing System (GoMOOS) (http://www.gomoos.org/). CODAR transmitters on Green Island, Maine and Cape St Mary, Nova Scotia provide hourly estimates of the surface currents in the northeastern Gulf of Maine. Additional stations are planned so that eventually the entire Gulf will be covered. Canadian members of GoMOOS include the Atlantic Pilotage Authority, Bedford Institute of Oceanography, OEATechnologies, StAndrews Biological Station, Saint John Marine Pilots and Satlantic Inc. The project also includes instrumented moorings measuring currents, winds waves, temperature, salinity and optical properties at selected sites throughout the Gulf. These data are reported back to shore in real-time and are combined with CODAR and satellite data. The combinations are used directly and to drive ocean models that provide information on waves, currents, temperatures and water quality to a variety of marine interests throughout the Gulf of Maine.

Over much of the US continental shelf, regional ocean observing systems such as in the Gulf of Maine are being established through partnerships among federal, state and academic agencies. The regional structure is necessary because the design and operation of these systems is still an area of active research. User needs from region to region differ and this will influence the regional designs. However, the American goal is to combine these regional systems into a national one that will provide real-time ocean data to support marine operations and marine and environmental safety over all US national waters. Ocean information will be available at the click of a mouse to responders to future marine emergencies in US waters.

\section{OCEANOGRAPHY IN SUPPORT OF INSHORE ACTIVITIES}

Inshore environments such as harbours, embayments and shorelines present special challenges to physical oceanographers. Local topography and bathymetry affect the winds and currents on spatial scales far smaller than any regional operational model can hope to deliver. In these shallow environments, issues related to the accuracy of the chart datum and changes to water depths and shorelines resulting from sedimentation, shoreline erosion, dredging and shoreline development become very important. Many of the bays and inshore waters of Atlantic Canada, particularly in Newfoundland and Labrador, have not even been surveyed by modern hydrographic methods. For heavily used environments, it is critical to develop the expertise and tools to observe and model waves, currents, tides and water quality in order to reduce impacts of multiple uses.

Much inexpensive instrumentation is available for use in shallow waters and can be mounted easily on jetties, aquaculture cages and light moorings that can be deployed from small boats. Because the instruments are moored 
close to land, their data often can be brought ashore via radio or cell phone links or through underwater cables. However, these environments are also biological hot spots or subject to high levels of human traffic. Instrument failure caused by biological fouling or vandalism is a frequent occurrence. In Atlantic Canada, we also have the problem of freezing in much of our coastal environment. This means that moored real-time systems cannot rely on a surface float and radio communication through the winter months; underwater cables must be protected from sea ice scour at the shoreline.

Because the equipment is relatively inexpensive and easy to use, a number of individuals make regular oceanographic measurements for their own purposes. Operators of lobster pounds, aquaculture sites and thermal power plants regularly measure ocean temperatures and perhaps other parameters such as salinities or oxygen concentrations. Few of these observations are documented or archived to contribute to an overall understanding of the climatology of the Atlantic Canada inshore environment. The Department of Fisheries \& Oceans (DFO) developed a program in the 1970s to measure coastal water temperatures at sites around Atlantic Canada. The data collected have allowed the climatological seasonal temperature cycle in the upper 12 metres to be produced for all of the North Atlantic Fisheries Organization (NAFO) sub-areas of Atlantic Canada. This climatology is available from the website address: http://www.mar.dfo-dpo.gc.ca/science/ocean/coastal_temperature/coastal_temperature.html

While these coastal temperature data provide basic information needed to design a water intake for a lobster pound or a power plant, they do not help with day-to-day operations. Measuring the temperatures at the intake, allows the operator to respond to varying conditions, but provides no warning of approaching changes. Real-time observing systems can be designed and integrated with ocean models so that operators could get several days warning of the possible onset of adverse conditions that could impact their operations.

Pilot observing systems have been established as research projects in a few selected embayments. Dalhousie University's Centre for Marine Environmental Prediction is running such a program in Lunenburg Bay. An array of weather stations and instrumented oceanographic buoys around this coastal embayment is providing real-time data to a fine scale coupled atmosphere - ocean model of the system. While this is a research project, it was used in a quasi-operational way during the World Youth Sailing Championships in July 2002 to provide detailed analyses and predictions to the competitors of both winds and currents.

\section{CONCLUSIONS}

Physical oceanography over its first twelve decades has developed the theoretical understanding as well as the observational, analytical and modeling tools to design and operate ocean observing systems that can deliver 
reliable information from the open ocean, shelf seas and inshore environments. With existing technology, local ocean information systems are already being operated in support of a number of marine activities, e.g. vessel routing services, naval operations in the open ocean, ice management, platform control information, sea surface height and wave information. In Canada and other countries, research groups are capitalizing on these advances by developing and testing improved systems for these purposes.

Oceanographers in Atlantic Canada have been in the forefront of many of these developments. Because Atlantic oceanographers are a small community located within a handful of government and academic research institutions, the boundaries separating basic, targeted and applied research have not been as strong as on the larger oceanographic world stage. As a result many of the tools and techniques required for the new generation of ocean observing systems conceived by Atlantic Canadian researchers have been developed readily and directly into commercial products through partnerships with Atlantic Canadian companies.

Currently oceanography in Canada is at a crossroad. From the 1960 s to the 1980s the federal government made a large investment, much of it in the development of the federal oceanographic laboratories and in the research fleet. During the deficit cutting of the 1990s, however, these resources shrank significantly. Scientists and technicians were not replaced when they retired, oceanographic instrument inventories have decreased and the fleet was reduced to a single 42 year-old multi-purpose vessel serving Atlantic Canada. At the same time, however, there has been some growth in the academic community in response to the government's Innovation Agenda which has allowed Canada to continue to carry out world class research projects on important oceanographic issues. However, because they are carried out largely by post-doctoral research fellows and students who leave at the projects' end, the projects tend to be relatively short-term.

Over the next decade, western Europe and the US will develop ocean observing systems covering most of their shelf seas. These will provide real-time ocean information to serve a variety of needs for marine and environmental safety, vessel and offshore operations, improvement of coastal and marine weather forecasts and fisheries management. The global ocean climate observing systems will still be providing observations on climate change and variability from the deep sea. If Canada is to continue to be a full participant in oceanography, it will need to reinvest in its oceanographic community by renewing its personnel, research fleet and instrumentation. As the oceans are a key component of the economy and life of Atlantic Canada, this oceanographic knowledge and information is needed so that the ocean resources can be used safely, co-operatively and wisely. 


\section{REFERENCES}

Baumgartner TR, Soutar A, Ferreira-Bartrina V (1992) Reconstruction of the history of Pacific sardine and northern anchovy populations over the past two millennia from sediments of the Santa Barbara Basin, California. CalCOFI Report 33:24-40

Bjerkan P (1919) Results of the hydrographical observations made by Dr. Johan Hjort in the Canadian Atlantic waters during the year 1915. In: Hjort J (ed) Canadian fisheries expedition, 1914-1915: investigations in the Gulf of St. Lawrence and Atlantic waters of Canada. Department of the Naval Service, Ottawa, ON, p 347-403

Craigie EH (1916)A hydrographic section of the Bay of Fundy in 1914. Suppl $5^{\text {th }}$ Ann Rept Canada Dept Naval Service, Fisheries Branch, Ottawa, ON, p 163-167

Campbell NJ (1985) Henry Benedict Hachey 1901-1985. Can J Fish Aquat Sci 42:1850-1851

Finney BP, Gregory-Eaves I, Sweetman J, Douglas MSV, Smol JP (2000) Impacts of climatic change and fishing on Pacific Salmon abundance over the past 300 years. Science 290:795-799

Grant AB (1968)Atlas of oceanographic sections. ReportAOL 68-5, Atlantic Oceanographic Laboratory, Bedford Institute, Dartmouth, NS. Unpublished manuscript

Hachey HB (1961) Oceanography and Canadian Atlantic waters. Bull Fish Res Bd Can 134

Sandstrom JW (1919) The hydrodynamics of the Canadian Atlantic waters. In: Hjort J (ed) Canadian fisheries expedition, 1914-1915: investigations in the Gulf of St. Lawrence and Atlantic waters of Canada. Department of the Naval Service, Ottawa, ON, p 221-243. 